\title{
PEDRO HESPANHOL: UM BANDIDO CÉLEBRE NO IMPÉRIO BRASILEIRO ${ }^{1}$
}

\author{
Pedro Hespanhol: a famous bandit in the Brazil \\ Empire
}

Ana Gomes Porto ${ }^{*}$

\begin{abstract}
RESUMO
Análise das representações de Pedro Hespanhol, que começaram a circular na imprensa brasileira em meados da década de 1830 , estendendo-se até o século XX. O artigo indagará os motivos que fizeram com que Pedro Hespanhol, considerado um criminoso "sanguinário", se transformasse em uma espécie de herói, sendo, inclusive, personagem de duas narrativas ficcionais.
\end{abstract}

Palavras-chave: criminosos na imprensa, Pedro Hespanhol, imprensa e romance

\begin{abstract}
Analysis of the representations about Pedro Hespanhol, which began circulating in the Brazilian press in the 1830s, extending until the twentieth century. It will be considering the reasons of Pedro Hespanhol was represented like a "cruel" criminal and, at the same time, turned into a hero and being mainly character in two fictional narratives.
\end{abstract}

Key-words: criminal in the press, Pedro Hespanhol, press and novel

1 Este artigo parte de reflexões feitas a partir de um capítulo da minha tese de doutorado Novelas sangrentas: literatura de crime no Brasil (1870-1920). Departamento de História, IFCH, Unicamp, 2009. Pesquisa desenvolvida com financiamento da CAPES e FAPESP.

* Pesquisadora de pós-doutorado (FAPESP) no Departamento de Teoria Literária, Instituto de Estudos da Linguagem, Unicamp. E-mail para contato: angomesporto@gmail.com 
Pedro Espanhol

Era ladrão,

Viveu matando

Por perdição.

Viveu matando

Por agonia,

Roubando o povo

De noite e dia.

De noite e dia

Por seu pecado

Sempre viveu

Desesperado.

De clavinote,

E de punhal,

Viveu fazendo

Somente o mal.

Pedro Espanhol,

Faca na mão,

Foi amarrado

Para a prisão.

Alvíssaras ao povo

Desta Cidade;

Morreu no Aljube

Este malvado.

Morreu no Aljube

Sem ter perdão.

Ficamos livres

Deste ladrão.

Morreu no Aljube

Por seu destino;

Ficamos livres

Deste assassino. ${ }^{2}$

2 "Cantiga de Pedro Espanhol". Em CASCUDO, Luis da Câmara. Flor de Romances Trágicos. Natal: EDFRN, 1999, (3 $3^{\mathrm{a}}$ edição), pp. 161-2. 
De início, uma explicação: Pedro Hespanhol era português. De acordo com A Verdade: "Este Pedro, conhecido por Hespanhol, era natural de Portugal". ${ }^{3}$ Certamente, o sobrenome "Hespanhol" confundiu os contemporâneos ou mesmo os levou deliberadamente a relacionar "Pedro Hespanhol" a "Pedro, o hespanhol". Ao percorrer as páginas da imprensa ao longo do século XIX, são várias as menções a indivíduos com o sobrenome Hespanhol. Entre os passageiros de paquetes, os "Hespanhol" estiveram no Brasil antes e após a morte de Pedro.

Não pretendo, com isso, investigar se Hespanhol era um sobrenome ou uma alcunha. Contudo, torna-se relevante que, nas diversas narrativas sobre o bandido ao longo do século XIX, Pedro Hespanhol tenha se transformado em Pedro hespanhol, natural da Hespanha. Mesmo nos anúncios da obra de Moreira de Azevedo, Criminosos célebres. Episódios históricos (em que uma das narrativas é a história de Pedro) havia variações entre Hespanhol e hespanhol. ${ }^{4}$ Torna-se particularmente relevante chamar a atenção para este caso, pois Moreira de Azevedo aponta que, para se ater à "verdade histórica", não iria "certificar o solo pátrio do nosso famigerado herói", mesmo tendo o mesmo Pedro "confessado haver nascido em Portugal, quando interrogado". 5

O que se pretende neste texto será analisar as representações de Pedro Hespanhol na imprensa, dando atenção especial aos jornais do Rio de Janeiro desde a década de 1830, quando começaram a aparecer notícias sobre o criminoso, até o ano de 1884, em que José do Patrocínio escreveu o romance Pedro Hespanhol no espaço de folhetim da Gazeta da Tarde sendo, logo em seguida, publicado sob a forma de livro pela tipografia do mesmo jornal. ${ }^{6}$

A imagem criada em torno deste "bandido célebre" foi construída em meio a um determinado contexto social em que a suspeição aos libertos, africanos livres e escravos esteve no centro das

3 A Verdade, 3 de maio de 1834.

4 Correio do Brazil, 3 de setembro de 1872 e Conservador, 5 de agosto de 1876.

5 AZEVEDO, Moreira de. Criminosos célebres. Episódios históricos. Rio de Janeiro, Garnier, 1872 , pp. 5 e 6.

6 A 1a edição deste romance se encontra na biblioteca da Fundação Casa de Rui Barbosa. 
atenções das autoridades públicas brasileiras. Da mesma maneira, as revoltas do período criaram representações diversas acerca dos indivíduos que estavam sob a mira da justiça, especialmente aqueles que pertenciam às camadas mais pobres da população. Por outro lado, nota-se o aparecimento, nas páginas da imprensa, de um grupo específico de sujeitos, os "malfeitores". Pedro Hespanhol fazia parte deste grupo.

Além de me concentrar na análise das imagens em torno de Pedro Hespanhol, pretendo, portanto, compreendê-las em meio à formação do Estado imperial brasileiro, particularmente no que concerne às representações de outros sujeitos considerados criminosos. O foco estará no bandido que se tornou legendário. Porém, cabe a indagação: por que Pedro Hespanhol foi citado tantas vezes, transformou-se em personagem de uma narrativa sobre criminosos célebres de Moreira de Azevedo na década de 1870 e herói do romance de José do Patrocínio em 1884? Quais as características deste criminoso que o levaram a ocupar este espaço? Pode-se cogitar a hipótese de que um bandido reconhecidamente "sanguinário" tenha se transformado em um "herói"? Em que medida isso é possível? Afinal, que herói é esse? Estas são questões importantes para pensar os motivos que fizeram com que Pedro Hespanhol permanecesse tanto tempo nas páginas da imprensa.

\section{Finalmente, o bandido está morto.}

As notícias sobre Pedro Hespanhol começaram a aparecer na imprensa brasileira na década de 1830, apesar da hipótese de que ele tenha chegado ao Brasil próximo da vinda da Corte. $^{7}$ "Homem

7 De acordo com AZEVEDO, Moreira de. op.cit. e LIMA, Hermeto. A história dos crimes célebres. Pedro Hespanhol (Recordações históricas coligidas pelo Dr. Hermeto Lima, do Gabinete de Identificação do Rio de Janeiro). Em A Noite, 1 de novembro de 1929. A história de Pedro Hespanhol foi a primeira de uma série de histórias sobre "criminosos célebres" publicada pelo jornal $A$ Noite. 
perverso", "famoso chefe de bandidos", "famigerado assassino", "temível ladrão" são alguns dos termos utilizados para designar Pedro Hespanhol na década de 1830 nos jornais brasileiros. Naquela época, não existia uma imprensa de entretenimento. ${ }^{8}$ As páginas das inúmeras folhas da Corte estavam recheadas de comentários que indicavam de maneira clara qual a posição defendida pelo jornal na disputa política. Caramurus, moderados e exaltados eram termos que apareciam com frequência. Mas também desordeiros e anarquistas. Estes dois últimos termos diziam respeito às relações negativas que os redatores das folhas mantinham com os participantes das inúmeras revoltas que assolaram o país a partir da década de 1830. O termo "anarquista" era muitas vezes, também, utilizado ao lado do termo "caramurus" pelos moderados. Neste último sentido, a ideia era mostrar que nenhum dos dois grupos era benquisto. ${ }^{9}$

O período que se estende entre as décadas de 1820 a 1840 caracteriza, no Brasil, a formação de uma imprensa artesanal, ${ }^{10}$ diferente daquela que surge após o início da publicação de folhetins. Os periódicos demarcavam um campo político em que se digladiavam os diferentes grupos. Opinativa por excelência, foi responsável pela formação de uma esfera pública, na medida em que possibilitou a

$8 \mathrm{O}$ primeiro folhetim publicado no Brasil foi em 1839 no Jornal do Commercio. A partir de então, tornou-se uma prática a tradução de autores estrangeiros e mesmo a publicação de folhetins brasileiros. Marlyse Meyer. Folhetim. Uma história. São Paulo: Companhia das Letras, 1996 e HENEBERG, Ilana. La suite au prochain numéro: Formation du roman-feuilleton brésilien à partir des quotidiens Jornal do Commercio, Diário do Rio de Janeiro et Correio Mercantil (1839. 1870) - Orientadora: Mme Jacqueline Penjon - Université de la Sorbonne Nouvelle - Paris III, 2004.

9 Ver, por exemplo, O Sete de Abril, Rio de Janeiro, 1 de janeiro de 1933. Morel, analisando as cartas da diplomacia francesa no Brasil, considera a existência de três "partidos": restaurador (Caramurus), liberais brasileiros (Moderados) e anarquista (Exaltados) (p. 73). Ainda de acordo com o mesmo autor, as alianças entre os grupos políticos mudava com rapidez. (p. 76). Por outro lado, cada diplomata tinha uma visão particular sobre os grupos, apontando para uma variação de sentidos em decorrência das peculiaridades do jogo político brasileiro, em que as coligações se alternavam rapidamente. Assim, um diplomata caracterizou o "Partido Anarquista" como um grupo republicanista e descentralizador, com a seguinte composição social: "um amálgama entre camadas pobres urbanas, grupos oprimidos do ponto de vista étnico e social com possibilidade de se expressar na cena pública e críticos em relação aos portugueses como representantes da permanência de estruturas herdadas da antiga metrópole ibérica." MOREL, Marco. As transformações do espaço público. Atores políticos e sociabilidades na cidade Imperial. São Paulo, Editora Hucitec, 2005, pp. 73, 76 e 77.

10 ibidem, p. 203. 
discussão política a partir de pontos de vista divergentes do grupo que estava no poder. ${ }^{11}$

A partir da abdicação de D. Pedro I em 1831, houve uma "verdadeira explosão da palavra pública". ${ }^{12}$ Certamente, este fato tem relação com a sensação transmitida pelos contemporâneos de que se vivia um momento revolucionário. De acordo com o programa do jornal $O$ Sete de Abril, criado em janeiro de 1833: "O dia Sete de Abril de 1831, em que a Providência concedeu à este Império, mais um favor, dando ao mundo o espetáculo de uma revolução, de que o seu maior sucesso, a abdicação - não custou à Nação, uma vítima, uma só gota de sangue, um só tiro (...). ${ }^{13}$ Defendendo um "credo político"14 e descrevendo-o no primeiro dia de publicação, o redator deixava bem claro que o jornal discutiria a política brasileira.

Não há dúvida de que a imprensa da época estava voltada ao debate político e à formação da opinião pública. ${ }^{15}$ Considerando isso, torna-se particularmente relevante uma notícia sobre a morte de Pedro Hespanhol, em um jornal que reproduz um texto do Jornal do Commercio. O jornal A Verdade, Jornal Miscellanico foi criado em 1832 e defende, em seu programa, que é partidário da "ordem" em oposição aos "vícios e à licença que se tem apoderado dos prelos". ${ }^{16}$ "Ordem", neste contexto, significa uma posição contrária aos jornalistas que escrevem para os "jornais anárquicos". A referência diz respeito aos partidários de um republicanismo exaltado, ao qual o jornal faz oposição. Pelo programa, pode-se ainda perceber que a folha se insere entre tantas outras da época: produzida artesanalmente (um grupo de 40 acionistas, dentre os quais aqueles que a redigem) e política (apesar de dizer, em seu primeiro número, que "tanto quanto possível [misturará] o útil ao agradável").

O fato é que, em abril de 1834, $A$ Verdade publica um longo artigo - que ocupa quase uma página inteira do jornal de quatro páginas - atendo-se à captura e morte de Pedro Hespanhol. A

11 ibidem, pp. 206-7. Sobre a formação de uma esfera pública na corte ver o trabalho de Morel, Marco. op.cit..

12 ibidem, p. 209.

13 O Sete de Abril, Rio de Janeiro, 1 de janeiro de 1831. Itálicos no original.

14 ibidem.

15 Sobre o tema ver Morel, Marco. op.cit. .

16 A Verdade, Rio de Janeiro, 25 de fevereiro de 1832. 
narrativa se assemelha àquelas que passaram a ser comuns a partir das décadas finais do século XIX nos mais variados jornais. Havia uma história a ser contada em todos os seus pormenores: descrição dos personagens, momento em que se passa a ação, sequência de quadros narrativos.

Assim, o leitor sabe que Pedro Hespanhol foi preso e morto por causa de uma "cilada" que os habitantes e um destacamento de Permanentes fizeram nas imediações de Inhaúma: "Havia alguns dias que Pedro rondava as imediações de Inhaúma, e com a maior destreza imaginável desaparecia de um lugar, e tornava a aparecer n'outro, e desta maneira, fazia insuficientes as medidas tomadas pelo Sr. Chefe de Polícia."

Sabe-se, também, que a prisão do bandido não foi nada fácil. Como inúmeras notícias de crime, o leitor tem a impressão de que o redator estava presente no decorrer da ação: ${ }^{17}$ Pedro vestia "à mineira", com um "poncho" e estava "à cavalo". Assim que lhe deram voz de prisão, "tirou as suas pistolas". Em resposta ao ato, "uma descarga bem dirigida não lhe deu tempo de fazer uso de suas armas, e ele, coberto de mais de 50 feridas, caiu e ficou no poder da justiça".

A notícia continua dando detalhes da operação: foi "amarrado" sobre um carro e conduzido à prisão da cidade por volta da meia-noite, "acompanhado de um povo imenso". Depois disso, o narrador detalha o vestuário de Pedro: "poncho guarnecido de veludo carmesim, e com galões de ouro, e botões de diamantes; trazia consigo uma corrente e relógio de ouro o mais rico possível, o qual se fez em pedaços com duas balas que lhe acertou".

Finalmente, o desfecho: morreu na prisão "pelas 11 horas da manhã, depois de ter recusado os socorros da religião". E mais detalhes: "O seu corpo e os seus braços são quase cobertos de várias caveiras, e outras figuras as mais obscenas ali se veem representadas. Algumas horas antes de morrer, pedia que lhe dessem uma faca para acabar mais depressa a sua existência, e dizia que se queria matar,

17 Ver, particularmente, o capítulo 2 do meu mestrado. PORTO, Ana Gomes. Sangue, gatunagem e um misterioso esqueleto na imprensa do prelúdio republicano. Mestrado em História Social. Campinas, S.P., Depto. de História, IFCH, Unicamp, 2003. 
envergonhado de ter sucumbido diante de paisanos". Após os pormenores da morte e do corpo, o redator ainda ressalta o "grande efeito produzido por este acontecimento", que levou "um sem número de povo [que] correu à Cadeia, para ver o corpo de Pedro logo que se soube que este famoso ladrão ali se achava encerrado."18

As notícias de crime na imprensa apareciam, em muitos casos, sob a rubrica "Notícias diversas" ou "Fatos diversos". Os jornais também noticiavam crimes de grande repercussão ocorridos no exterior. Da mesma forma, escreviam em detalhes - normalmente todos os dias e ocupando um espaço razoável - eventos em torno de um "grande crime"19 que acabara de ocorrer. Esse processo começou, grosso modo, a partir da década de 1870 e se intensificou brutalmente a partir das primeiras décadas do século XX. "Crimes sensacionais", "notícias sensacionais", "caso sensacional" eram termos comuns e corriqueiros nos jornais. Movimento semelhante ocorria em relação aos livros centrados em histórias de crime, que tinham o subtítulo "romance sensacional" ou indicavam na capa a característica de uma "história de sensação". Tais livros poderiam ser completamente ficcionais, mas também poderiam se basear em crimes verídicos, sendo o limite entre realidade e ficção bastante estreito. ${ }^{20}$

Para o interesse deste artigo, cabe apontar que havia uma determinada maneira de suscitar o interesse do leitor a partir de um efeito que poderia ser mais ou menos sensacional. ${ }^{21}$ Este efeito estava na maneira de construir a narrativa, enfatizando alguns elementos em detrimento de outros. Ao mesmo tempo, os folhetins e os fascículos de romances se baseavam numa intriga que gerava suspense, havia efeitos dramáticos derivados do melodrama e a ação funcionava como

18 A Verdade. 3 de maio de 1834 . As citações anteriores são do mesmo dia.

19 Sobre o tema ver PORTO Ana Gomes. op.cit. e PORTO, Ana Gomes. Novelas sangrentas: literatura de crime no Brasil (1870-1920). Doutorado em História Social. Campinas, S.P., Depto. História, IFCH, Unicamp, 2009.

20 Ver KALIFA, Dominique. L'Encre et le sang. Récits de crime et société a la Belle Époque. Paris, Éditions Fayard, 1995 e a minha tese de doutorado PORTO, Ana Gomes. op.cit.

21 Nos dias de hoje, o termo seria "sensacionalista" e, de fato, foi a partir das "notícias sensacionais" que se construiu aquilo que passou a ser conhecido como sensacionalista. Utilizarei o termo "sensacional" para não cometer anacronismo. 
um catalisador para instigar a curiosidade em torno de crimes indecifráveis e criminosos definidos como espertos e sagazes. ${ }^{22}$

Esta literatura de crime publicada no Brasil caminhou em paralelo à publicação de folhetins. Havia semelhanças em torno da forma narrativa, porém com o diferencial de que os romances de crime tinham como elemento central a história de um crime ou criminoso. Mesmo não sendo tão comum como nas décadas finais do século XIX, pode-se encontrar alguns títulos, como $O$ célebre salteador Vidocq no ano de 1852 no Correio Mercantil ou El Salteador, roman de cape et d'epée, romance de 2 volumes à venda na Livraria Garnier e anunciado no Correio Mercantil em $1854 .^{23}$ Assim, após o início da publicação de folhetins no Brasil em 1839, é possível considerar que os leitores passaram a ter contato com uma determinada maneira de escrita mais palatável, a qual se concentrava no espaço dedicado ao entretenimento, mas que, com o tempo, ampliou-se para as outras colunas do jornal. Este fenômeno foi observado na França e também ocorreu no Brasil. ${ }^{24}$

Em relação às notícias de crime, foi substancial a inclusão de elementos próprios das narrativas ficcionais, gerando colunas em que o leitor ficava em dúvida se o crime era real ou imaginário. ${ }^{25}$ Contudo, neste ano de 1834, nenhum destes recursos era comum. Apesar disso, na notícia sobre a morte de Pedro Hespanhol é perceptível a utilização de uma determinada forma própria de uma narrativa ficcional. De fato, não era comum nem ao menos o tipo de notícia: sobre um criminoso. Antes de imaginar que esta notícia está "fora de lugar", devemos fazer o processo inverso e entender os motivos que levaram os jornais a comentarem de maneira detalhada e com recursos próprios das narrativas de crime a captura e consequente morte de Pedro Hespanhol.

22 Desenvolvo uma análise em torno das características de romances de crime na parte 2 - "Narrativas" da minha tese de doutorado.

23 Anúncio do Correio Mercantil, Rio de Janeiro, 17 e 19 de novembro de 1852.

24 Sobre o tema na França ver, especialmente, THÉRENTY, Marie-Ėve. La littérature au quotidien. Poétiques journalistes au XIXème siècle. Paris, Seuil, 2007.

25 Ver PORTO, Ana Gomes. "Um esqueleto no Paço imperial. Literatura e política em alguns folhetins no início da República". Em Cadernos AEL. Volume 9, 16/17, Campinas, S.P., 2002. 
Uma diferença substancial desta notícia para as notícias de crime que começaram a aparecer a partir das décadas finais do século XIX está no fato de que não houve detalhamento dos crimes de Pedro e sua quadrilha. Pela notícia da sua morte, sabemos que ele cometeu, ao menos, 26 assassinatos. Contudo, não há descrição dos crimes. A partir de uma pesquisa nos periódicos do Rio de Janeiro, encontra-se referência apenas a notícias ao longo do ano de $1834 .{ }^{26}$ Um jornal do final do século exploraria todos esses crimes no momento em que eles ocorreram, detalhando-os, apontando suspeitos e chamando a atenção para a possibilidade de que pudesse ser um crime de Pedro Hespanhol. Mas, neste caso, isso não ocorre e há apenas notícias muito próximas à sua morte, em que já sabemos que ele cometeu roubos e assassinatos. Além disso, parece existir um consenso em relação à impunibilidade de seus crimes: Pedro Hespanhol deveria ser capturado e, principalmente, punido.

A notícia de $A$ Verdade mostra que a população estava indignada com a presença do "famoso ladrão"27 na vizinhança. Este sentimento também foi apontado em outro jornal, O Sete de Abril, no mesmo ano de 1834:

Passeia por esta Corte o desumano Pedro Hespanhol (...). Assassinando e roubando, como lhe apraz, conserva muitas e boas amizades, e a prisão não tem sido para ele outra coisa mais que um golpe de bolsa! Aparece pelas ruas da cidade com trajes mudados 6 a 7 vezes ao dia; mora em todos os bairros, e tem a seu soldo quem o avise apenas, para ser capturado, se dá algumas dessas ordens mancas, sem habilidade, nem sigilo; entretanto as famílias se assustam só ao ouvirem dizer - passou por aqui o Pedro Hespanhol - e nos subúrbios da cidade muitos chefes de família, temem a todas as horas da noite verem-se acometidos por alguma das companhias de

26 Pesquisa realizada na Hemeroteca da Biblioteca Nacional. Apesar da pesquisa na Hemeroteca não ser totalmente confiável em relação aos resultados quando se faz a busca por "palavra-chave", o fato de que não foi encontrada notícias de crime como nos jornais de final do século é um grande indicativo de que não houve notícias sobre os crimes de Pedro Hespanhol na época em que foram cometidos.

27 A Verdade. 3 de maio de 1834. 
ladrões, que estão debaixo do comando desse formidável e (permita-se-me dizê-lo) inviolável salteador. ${ }^{28}$

Nesta notícia, fica evidente que o "famoso ladrão" permanece impune em decorrência de relações com pessoas importantes "conserva muitas e boas amizades". Em paralelo, outra imagem: Pedro é inteligente e audaz. Como consequência, "as famílias se assustam". Finalmente, a conclusão: Pedro é um "formidável e inviolável salteador", sendo que a característica de "inviolável” é escrita quase em tom de desculpas pelo redator, como se fosse dizer algo proibido: "permita-se-mo dizê-lo".

Definitivamente, não se tratava de um bandido qualquer. Pedro conseguia viver naquela sociedade quase como um cidadão, equivalente àqueles que escreviam e liam as notícias políticas dos periódicos. "Passeava pelo Corte" e ainda travava relações com pessoas importantes. Situação praticamente inadmissível, tanto que aparece nas páginas da imprensa apenas em um momento em que se tornava impossível suportar a sua presença na sociedade, ou seja, quando houve um movimento para prendê-lo, vivo ou morto.

Mas, para além da vontade de acabar com a lenda viva, permanecem algumas imagens não necessariamente negativas. Assim, apesar de um bandido reconhecidamente sanguinário, foi considerado "formidável". A notícia da captura e morte de Pedro acentua a sua valentia, já que não se rendeu à prisão, apesar da grande quantidade de homens que o cercaram. Além disso, o redator não deixa de notar a riqueza do seu vestuário. Certamente, a sua intenção foi mostrar que Pedro roubou demais, mas, para além disso, indica um homem que detinha um certo poder. Não deixa de ser impressionante que, para capturá-lo, tenha sido necessário, além do corpo de Permanentes, a ajuda da população.

De fato, era um homem excepcional e, por isso, transformouse em notícia na imprensa. Mas, apesar de algumas similitudes em relação à forma das notícias de crime corriqueiras anos à frente, esta se fixa apenas no momento da captura e morte do bandido. Mas não 
deixa de ser relevante que houve um movimento bastante semelhante em relação ao bandido. Como outros criminosos que ficaram famosos anos mais tarde, Pedro ganhava uma notoriedade dúbia, em que o medo decorrente da sua característica de "homem perverso" e "famigerado assassino" igualava-se a uma certa admiração pela sua sagacidade e valentia.

Parodiando o redator do jornal $O$ Sete de Abril, esta imagem permanecerá "inviolável", apesar de ser apresentada de diversas maneiras. Os itens seguintes mostrarão os caminhos de Pedro após a sua morte. A representação do "famoso ladrão" se modificou ao longo do tempo, mas permaneceu no imaginário daqueles que viveram os anos e as décadas seguintes. Pedro Hespanhol fez, em certa medida, parte da história da construção do Império brasileiro.

\section{Pedro Hespanhol, malfeitores e desordeiros.}

Em 1840, o jornal O Brasil apresenta, na primeira página e em destaque, uma grande reportagem, cujo título é "Os movimentos populares". ${ }^{29}$ A preocupação central do artigo (sem assinatura) está em mostrar o grande perigo de instigar um determinado grupo de homens (denominado de "plebe") à ação revolucionária. Para o redator, "a veemência das paixões desses homens, a falta absoluta ou o acanhamento de suas faculdades intelectuais, a pobreza em que vivem, fazem deles a matéria sempre disposta para todas as revoluções, os desgraçados instrumentos de todas as violências".

$O$ Brasil defendia os interesses conservadores. De acordo com Sodré, ${ }^{30}$ Paulino José Soares queria um jornal que compactuasse da opinião ministerial e convida Justiniano José da Rocha para escrevê-lo. Acompanhando as diversas notícias da folha, nota-se que há uma crítica às ações dos liberais e uma opinião favorável às ações

29 O Brasil, Rio de Janeiro, 3 de novembro de 1840.

30 SODRÉ, Nelson Werneck. História da imprensa no Brasil. Rio de Janeiro, Mauad Editora, 1998, p. 289. 
dos conservadores, não importando se os mesmos estivessem ou não ocupando cargos ministeriais, ou seja, de acordo com a política da época, governando o país.

Para os nossos interesses o que importa são as relações feitas entre uma determinada classe de homens - chamada, neste artigo d' $O$ Brasil, de classes perigosas - e os políticos liberais. Como será possível perceber, várias imagens são acionadas para delimitar um grupo indesejável não apenas por esta folha: as chamadas "classes perigosas". Em alguns momentos, a relação com Pedro Hespanhol é direta. Assim, será possível estabelecer um determinado imaginário criado em torno dos "bandidos".

A imagem de Pedro Hespanhol esteve associada aos indivíduos que se desejava extirpar da sociedade. Permanece a impressão de um medo generalizado em relação àqueles que se assemelham ao famoso bandido. Esta característica aparecerá na imprensa a partir de alguns elementos que, de certa forma, são complementares. Um deles se refere aos que eram comparados a Pedro Hespanhol porque possuíam "boas amizades", ou seja, tinham relações com pessoas que detinham poder. $\mathrm{O}$ outro diz respeito à sagacidade e inteligência de alguns indivíduos. Vejamos como isso ocorreu a partir de algumas notícias.

As "classes perigosas" ainda eram uma novidade em 1840. Frégier acabara de ganhar o prêmio da Academia das Ciências Modernas em que delimitava e propunha formas de "melhorar" aqueles que faziam parte desta classe. ${ }^{31}$ De acordo com notícia do Journal des Débats publicada n'O Despertador, ${ }^{32}$ era uma classe de homens que vivia "ao lado da população rica, das classes laboriosas e das classes pobres". Homens e mulheres "ociosos", com "costumes seus, paixões suas" e que "deviam ser vigiados pela polícia".

O redator de "Os movimentos populares" sabia da publicação do livro de Frégier e fazia referência ao prêmio da Academia. Preocupava-se, especialmente, com o seguinte: "Mas entre nós o que é que se faz para esses homens?". "Esses homens" (a classe perigosa

31 FRÉGIER, H.A. Des classes dangereuses de la population dans les grandes villes, et des moyens de les rendre meilleures. Paris: J. B. Baillière, Libraire de L'Académie Royale de Medicine, 1840.

32 "Classes perigosas de Paris". O Despertador, Rio de Janeiro, 2 de outubro de 1840. 
no Brasil) eram "a plebe", ou seja, aqueles que viviam "no meio do povo". O "povo" representava a nação, pois estava composto de homens com direito ao voto, já que "detinham a renda líquida de cem mil réis pelo menos para poder intervir no exercício do direito de eleger." Portanto, "a plebe" ou "a classe perigosa" vivia "no meio do povo", não ficando muito claro se eram indivíduos pobres ou não. Mas qual o motivo de se tornarem "perigosos"?

De acordo com o redator, "individualmente, e nos momentos de calma, grandes virtudes lhes achareis". O problema estava em "agitar esta classe" como ocorreu "para produzir o dia 7 de abril de 1831, como para produzir todas as revoluções". Finalmente, a grande preocupação: "a sociedade brasileira correu então grave perigo; todavia não era ele tão iminente como agora". Como se sabe, logo após a abdicação de D. Pedro I, ocorreram inúmeros "motins" na Corte, além das revoltas espalhadas pelas províncias. Certamente, são a esses eventos que o artigo faz referência. Muitos ainda estavam em processo neste ano de 1840 e, no calor da hora, o medo exibido pelas palavras do redator d' $O$ Brasil: "E se algum demagogo mais ambicioso do que vós quiser contra vós concitá-los, como vos salvareis?" Ainda: "Ah! a escritura santa, a escritura santa é o mais precioso dos livros. Ela vos diz - quem semeia ventos colhe tempestades. - Ouvistes?!..”

Claramente, as palavras se dirigiam a um grupo específico de pessoas: aqueles que, de acordo com este artigo, "incitavam" as "classes perigosas". Membros, portanto, do "povo", mas que, em momentos de disputas pelo poder, como foram os anos que se seguiram à abdicação de D. Pedro I, momentaneamente uniam-se à "plebe".

As comparações com Pedro Hespanhol apareciam neste contexto de instabilidade política. Assim, em "Júbilos ministeriais", pequena notícia apontando uma possível fraude eleitoral: "Os ministeriais não achem em si de júbilo - vencemos a eleição na Corte, bradam - Ah! camaradinhas, para lutar convosco nessa porfia era preciso ser Pedro Hespanhol, tendo às suas ordens a sua quadrilha...mas esse herói, se fosse vivo, estaria ao vosso lado, seria 
o substituto do vosso capataz (...)". ${ }^{33}$ Associava-se os liberais a uma ação ilegal e, apesar da diferença temporal de quatro anos da notícia sobre as "classes perigosas", o discurso permanecia o mesmo, ou seja, de que um determinado grupo de políticos (os liberais) tinha ao seu lado membros das classes perigosas, no caso, de Pedro Hespanhol e sua quadrilha.

Ainda no mesmo ano de 1844, dois artigos do mês de novembro completavam o quadro de relações entre liberais e conservadores (aqui denominados de ordeiros e desordeiros). Há uma análise da situação das eleições para a Câmara dos Deputados em 14 de novembro. A partir de termos como "violências", "marombeiros", "marombas", "ordeiros decididos", "facção" conclui-se que "a maromba é de ordinário ministerial, forma ela o bojo da Câmara". A certeza de que "marombeiro" é sinônimo de "santa-luzia" (ou liberais) aparecia apenas no artigo de 28 de novembro. ${ }^{34}$ No dia 14 de novembro, contudo, fica patente uma preocupação: a de que o país está "em luta" e muitos pontos do Império "erguerão bem alto o seu grito de república e de separação", a não ser que "os amigos da ordem" consigam fazer alguma coisa contra estes movimentos separatistas.

No final do artigo, a lembrança de Pedro hespanhol (com $\mathrm{h}$ minúsculo): "a justiça assassinada, a moralidade pública completamente extinta, capaz de dar glórias a Pedro hespanhol, se Pedro hespanhol ressuscitasse!". Mais abaixo, a conclusão de que o país vivia um "drama horroroso":

No meio da luta das duas fracções (sic) parlamentares, todos os germens de miséria pública e de dissolução desenvolvendo-se, dando os seus frutos, eis o triste aspecto com que se nos apresenta o futuro do país!

33 O Brasil, 21 de outubro de 1844.

34 "Nós, os ordeiros, queremos que com todos os meios da lei, com toda a firmeza de uma sã política se obste que os santas-luzias subvertam a sociedade, e nela exerçam devastadora influência; eles querem, por outro lado, com todos os recursos da turbulência e da ditadura que nem nós, os ordeiros, nem as nossas ideias exerçam a menor influência no país (...)." ("Ui! O que quer dizer isto?" - O Brasil, 28 de novembro de 1844) 
E note-se que é tudo isso a terrível peripécia de um drama horroroso que se representa no país desde 1826; ora, nos dramas das nações, como nos dramas teatrais, quanto mais se aproxima o desfecho, tanto mais precipitam os acontecimentos...Os germens da ruína tem rápido e prematuro desenvolvimento, já dão fruto, quando nem ainda os reputaríeis em flor!... 35

A linha editorial do jornal $O$ Brasil cumpria aquilo que prometera em 1840 e mantinha uma postura crítica em relação à política, apesar da posição favorável aos conservadores (ou ordeiros). A referência a Pedro Hespanhol/hespanhol se desenvolve como parte de um "drama horroroso". Seria o país subjugado pelas "classes perigosas"? Neste caso, as glórias seriam de Pedro Hespanhol, que permanecia como representação daquilo que se temia: caos, desordem, domínio dos marombeiros ou desordeiros na política.

Se o medo rondava os lugares da política, surgia especialmente em relação aos indivíduos considerados das "classes perigosas". Neste caso, a comparação com Pedro era direta. Assim, o artigo do dia 9 de fevereiro de 1848 considera um absurdo que um "presidente de província vai ter com um chefe de salteadores em uma mata" para estabelecer um "tratado de paz". Para o redator do artigo, Vicente de Paula, era "conhecido como o salteador das matas de Jacuípe que desde 1844 foi o aliado do partido hoje dominante em Alagoas". Vicente de Paula é considerado um "incendiário, um assassino, um ladrão de profissão, como o foi Pedro hespanhol". ${ }^{36}$

Pedro Ivo e Caetano Alves também foram comparados a Pedro. No dia 5 de janeiro de 1850, um artigo d'O Brasil tem como argumento principal mostrar a influência de Pedro Ivo e Caetano Alves sobre a oposição, que publica o manifesto elaborado por ambos, considerados como "chefes dos bandos anárquicos que devastam as matas de Pernambuco". Ao comentar sobre a exigência de Pedro Ivo de ninguém "passear" por determinada estrada sem prévia autorização dada apenas por ele, o redator o relaciona a outros

35 "O resultado de tudo isto". Em O Brasil, 14 de novembro de 1844. 36 "Infầmia". Em $O$ Brasil, 9 de fevereiro de 1848. 
"heróis em luta aberta contra a sociedade", como Pedro Hespanhol no Rio de Janeiro. ${ }^{37}$

Após alguns artigos em que Pedro é designado como "hespanhol" com minúscula, "Hespanhol”, neste exemplo, está escrito com maiúscula. Erro de tipógrafo? Pode ser. Mas é relevante que a designação com maiúscula ou minúscula varia ao longo de todo o século, não necessariamente no sentido de transformar Pedro Hespanhol em Pedro, o espanhol, mas de uma maneira mais fluida, em que a variação cria uma aura mítica para o personagem. Talvez diluir a origem portuguesa de Pedro tivesse relação com as inúmeras revoltas em que os portugueses se tornaram foco da ira dos revoltosos.

Não houve intencionalidade nisso. Houve uma apropriação, decorrência de uma alteração de sentidos: ${ }^{38}$ Pedro passava a ser quase um herói de romance. "Formidável e inviolável salteador" como aponta o Sete de Abril em 1834. Vicente de Paula, Pedro Ivo e Caetano Alves, ao serem comparados com Pedro possuíam as mesmas qualidades. E, se no artigo d'O Brasil era um absurdo a negociação entre líderes políticos e estes "salteadores" e membros das "classes perigosas", talvez esta relação não fosse tão absurda para outros indivíduos: aqueles que não eram os leitores ou os redatores desta folha e talvez também fizessem parte do grupo que foi considerado como "classe perigosa". Daí, o medo evidente exibido nas colunas do jornal $O$ Brasil.

A imprensa tentava delimitar um certo grupo de indivíduos e termos como "classes perigosas", "malfeitores", "facínoras", "ladrões e vadios", "desordeiros", "bárbaros" eram utilizados para designar pessoas como Pedro Hespanhol, líderes de revoltas com características políticas (como as que seguiram o período da abdicação) e membros das classes mas baixas da população quando se envolviam em qualquer atividade considerada ilegal ou inadequada. Tratava-se de colocá-los em um lugar comum do imaginário e

37 ibidem.

38 "A apropriação, a nosso ver, visa uma história social dos usos e das interpretações, referidas a suas determinações fundamentais e inscritas nas práticas específicas que as produzem." Em CHARTIER, Roger. "O mundo como representação". Estudos Avançados, 11(5), 1991, p. 180. 
delimitá-los como "perigosos". Esse tipo de relação perdurou ao longo de várias décadas do século XIX.

Pedro Hespanhol, lembrado como "bandido sanguinário" e "célebre salteador" passou a fazer parte deste mesmo imaginário e se tornou referência para mais de uma citação nas páginas da imprensa. Tornara-se um personagem.

\section{Pedro Hespanhol: de bandido à personagem.}

Ao menos duas narrativas foram feitas em torno da história de Pedro Hespanhol. Uma delas foi escrita pelo "dr." Moreira de Azevedo. Não era incomum que a história de criminosos fosse contada a partir de narrativas em que o autor escolhia alguns criminosos famosos do passado. Este foi o caso de Criminosos célebres. Episódios históricos, publicado em 1873, em que o escritor conta três histórias: "Pedro Espanhol", "Vasco de Moraes" e "Os salteadores da Caqueirada". Apesar da existência de algumas notas de rodapé, que indicam notícias de jornais da época dos criminosos, de forma geral a narrativa é bastante diferente daquelas que o mesmo autor publicava na Revista do Instituto Histórico, Etnográfico e Geográfico Brasileiro. ${ }^{39}$

De forma geral, os artigos da Revista do Instituto faziam uma análise criteriosa e repleta de referências e notas de rodapé. Já os "episódios históricos" de Criminosos célebres eram narrativas detalhadas e longas, semelhantes a pequenas novelas. Apesar da intenção de "não alterar a verdade histórica", ${ }^{40}$ Moreira de Azevedo

39 O Instituto pretendia "construir uma história da nação" e, para isso, tinha uma "produção de cunho oficial": "Criado logo após a independência política do país, o estabelecimento [IHGB] carioca cumpria o papel que the fora reservado, assim como aos demais institutos históricos: construir uma história da nação, recriar um passado, solidificar mitos de fundação, ordenar fatos buscando homogeneidades em personagens e eventos até então dispersos." SCHWARCZ, Lilia Moritz. O espetáculo das raças: cientistas, instituições e questão racial no Brasil - 1870-1930. São Paulo: Companhia das Letras, 1993, p. 99 e 101.

40 AZEVEDO, Manuel Duarte Moreira de. Criminosos célebres. Episódios históricos. Rio de Janeiro: B. L. Garnier, [1873], p. 5. 
dava-lhes um formato de história ficcional. Assim, existe aventura, ação, drama e há determinados efeitos que convidam o leitor à continuidade da leitura.

O enredo segue um caminho parecido ao de outras narrativas de crime que começavam a aparecer na década de 1870. O início conta a história do criminoso desde a sua infância, ressaltando a má criação do menino. Em seguida, o primeiro crime que, no caso de Pedro, foi assassinar o homem que o criara. Poderia ser uma cena chocante se o leitor não soubesse que o padrinho e a sua "megera esposa" tratavam a criança "às palmatoadas e empurrões". ${ }^{41}$

Em diversas partes o autor fornece à narrativa um caráter dramático e descreve em detalhes as cenas de crime. Ao menos quatro momentos são relevantes para a história: o assassinato do padrinho que o coloca no "caminho do crime", o assassinato de sua amante, o encontro com Elisa e a morte de Pedro. O objetivo da história é mostrar o caráter do bandido: ele é homem mal. Apesar disso, em alguns trechos Moreira de Azevedo apresenta o personagem de maneira positiva. Assim, ressalta que Pedro possuía uma "fisionomia bela e expressiva, seu olhar, e a vastidão da sua testa manifestavam inteligência". 42 encontro com Elisa, moça que "encanta Pedro", é singular para a percepção de um homem com boas ações:

Nessa residência da praia da Gamboa encontraram os amigos de Pedro uma moça que, vendo-se rodeada de ladrões, ajoelhou-se ante eles, e rogou-lhes piedosamente a não assassinassem, assim como à sua mãe que se achava gravemente enferma; prometeu-lhes entregar tudo que era seu, se, compassivos, poupassem-lhe a vida e à de sua mãe enfermiça, mas mostravam-se desapiedados os assassinos, e estavam prestes a desfechar o golpe certeiro sobre a vítima humilhada, quando seu chefe, penetrando no recinto da habitação, impressionado da formosura da moça, ou tocado por seu pranto aflitivo, ordenou-lhes se afastassem, e não ofendessem aquela mulher, nem à que jazia no leito.

41 Idem, ibidem, p. 8.

42 Idem, ibidem, p. 14. 
Foi imediatamente obedecido, recolheram os sicários os punhais, e [se] retiraram silenciosos e apressados. ${ }^{43}$

Além de mostrar que Pedro foi "piedoso", indica a capacidade de domínio sobre a quadrilha. Seguindo a imagem que já vinha sendo construída em torno de Pedro Hespanhol desde 1834, a narrativa de Moreira de Azevedo salienta a sua inteligência, sagacidade e audácia, às quais se refletem em liderança.

Há três momentos que merecem reflexão na história de Moreira de Azevedo. Além do assalto à casa de Elisa, o momento da morte de sua amante, apelidada de "Batatinha" e a morte de Pedro na cadeia. Seguindo uma característica presente em diversas narrativas de crime - de notícias a histórias ficcionalizadas (baseadas ou não em um caso real) - percebe-se a presença de um determinado efeito que gera sensação.

O termo sofreu alterações ao longo do século XIX. No francês, a palavra "sensacional" é definida no dicionário como uma variável de sensação: "que faz ou é destinada a fazer sensação". "Sensacional" surgia na língua francesa em 1875 com o seguinte sentido: "Que faz sensação, produz uma viva impressão sobre o público. Um romance sensacional". ${ }^{44}$ Em português, houve uma modificação de sentidos ao longo do século XIX e início do XX: enquanto na edição de 1813 do dicionário de Antonio Moraes Silva a palavra "sensação" designava apenas um "sentimento, que a alma tem dos objetos por meio da impressão que eles fazem nos órgãos sensórios externos, ou no interno"; ${ }^{45}$ em 1939 o sentido era ampliado para: "surpresa ou grande impressão devida a sucesso extraordinário" e, na forma figurada, "comoção moral, sensibilidade". Como na

43 Idem, ibidem, p. 41-2.

44 Le nouveau Petit Robert. Dictionnaire alphabétique et analogique de la langue française. Montreal: Dicorobert, 1996, p. 2072.

45 SILVA, Antonio de Moraes. Dicionário da Língua Portuguesa recopilado dos vocabulários impressos até agora, e nesta segunda edição novamente emendado, e muito acrescentado. Lisboa: Tipografia Lacerdina, 1813, p. 687. 
língua francesa, houve o acréscimo da palavra "sensacional", que seria aquilo "que produz grande sensação."46

Houve, ainda, um gênero literário inglês de amplo sucesso na década de 1860 denominado "romances de sensação". A aproximação entre este gênero e o romance policial foi estabelecida em diversos momentos, como se pode perceber pelas críticas dos jornais ingleses em torno da obra de Emile Gaboriau, escritor de romances policiais franceses que, não por acaso, teria a tradução de seus romances na Inglaterra sob o título de Sensational Novels.

De maneira geral, uma narrativa com efeito sensacional apresentava cenas chocantes, como a descrição detalhada de crimes brutais. Mas também possuía uma relação direta com a forma de narrar. Um enredo carregado de suspense definia uma maneira de ler, a qual "apelava aos nervos" e aos estímulos sensoriais, excitando os sentidos, gerando uma "hiper-estimulação": 47 "os nervos dos leitores são afetados como os do herói". ${ }^{48}$.

A narrativa de Moreira de Azevedo não criava um efeito tão "sensacional" quanto o romance de José do Patrocínio, que veremos em seguida. Apesar disso, a morte de Pedro na prisão é particularmente importante para o enredo e este efeito. A finalização da narrativa com a sua morte revela o caráter ficcional da obra. Esta descrição foi feita pelo narrador de forma subjetiva e a partir de "experiências puramente internas", as quais só poderiam tomar parte em uma "biografia fictícia". A ação é exatamente a mesma apresentada naquela notícia da captura do criminoso em 1834. Pedro

46 LiMA, Hildebrando Lima e BARROSO, Gustavo (org.). Pequeno dicionário brasileiro da língua portuguesa. $2^{a}$ edição. Civilização Brasileira, Rio de Janeiro-São Paulo, 1939, p. 935.

47 DALY, Nicholas. Railway novels: sensation fiction and the modernization of the senses. In English Literary History. Baltimore, Maryland: The Johns Hopkins University Press, 1999, p. 466. Disponível em «http://links.jstor.org», acesso em 10.12.2007. Sobre comentários de contemporâneos em relação aos romances de sensação ver entre as pp. 462-466.

48 Mrs. Oliphant. Sensation novels. In Blackwoods 91, 1862. Apud por DALY, Nicholas. Op.cit., p. 462 e LOESBERG, Jonathan. The ideology of narrative form in sensation fiction. In Representations, $\mathrm{n}^{\circ} 13$ (Winter, 1986), p. 125. Disponível em «http://links.jstor.org», acesso em 19.12.2007.

$49 \mathrm{COHN}$, Dorrit. The distinction of fiction. Baltimore, Londres: The Johns Hopkins University, 1999, pp. 20-1. Segundo a autora: "Nenhum instante da vida (se esse pode ser chamado assim) ilumina mais dramaticamente a diferença entre ficção e biografia que morte e morrendo, entre a circunspecção do biógrafo e a liberdade do romancista." Idem, ibidem, p. 22. 
e José Algarve foram presos na freguesia de Inhaúma, em uma emboscada realizada pelo inspetor local. Ambos foram feridos, presos e conduzidos à cadeia do Aljube:

$\mathrm{Na}$ mesma noite em que o réu entrou na prisão começaram as suas agonias; as dores trucidavam-no, estorcegavam-lhe os membros as convulsões, partiam-lhe do peito gemidos agudos e penetrantes, e afogavam-no golfadas de sangue. O rosto confrangido, os olhos esbugalhados, os cabelos contraídos pintavam as agruras da dor, as angústias de aflição que roíam-lhe a alma. Ora procurava erguer-se, mas vacilava e caía envolto em sangue e em suor; ora ficava como entanguido (sic) e entregue a repentino letargo.

Como se espectros horrendos cercassem-no e quisessem arrebatá-lo, envolvia-se nos lençóis do leito, transido de medo; outras vezes enclavinhava os dedos, os olhos fuzilavam-lhe cheios de rancor, avançava e parecia querer despedaçar quem dele se aproximava. As dores traziam-lhe em alguns instantes lágrimas aos olhos, e o sangue espadanava-lhe de cinquenta feridas. ${ }^{50}$

A agonia de Pedro ainda é descrita por mais algumas páginas. Após a sua morte, o cadáver foi motivo de visitação na cadeia do Aljube. Os curiosos viam um corpo "esculpido de figuras": nomes de mulheres, caveiras, figuras obscenas, uma imagem de Cristo e da Virgem da Conceição, o bandido galopando em seu cavalo. ${ }^{51} \mathrm{~A}$ ficcionalidade impregna esta passagem. Moreira de Azevedo tenta transmitir não apenas que Pedro estava morrendo, mas que um criminoso cruel e terrível sofria barbaramente na hora da morte. Para isso, utiliza-se de uma determinada forma narrativa que tenta aproximar o leitor do personagem através da descrição detalhada de

50 AZEVEDO, Manuel Duarte Moreira de.Criminosos..., pp. 72-3. A morte de Pedro foi narrada subjetivamente, a partir de "experiências puramente internas". COHN, Dorrit. Op.cit., pp. 21.

51 Idem, ibidem, p. 74. 
Pedro nos momentos que antecederam a sua morte. A intenção é fazer com que o leitor sinta "na própria pele" o que o personagem estava sentindo como se os "nervos" dos leitores fossem equivalentes aos do herói.

Ainda houve outro Pedro Hespanhol. De autoria de José do Patrocínio, circulou sob a forma de folhetim na Gazeta da Tarde no ano de 1884, jornal comprado pelo mesmo escritor, em 1881. Em seguida foi publicado sob a forma de livro pela tipografia do mesmo jornal. A folha fazia, em 1884, concorrência à Gazeta de Notícias e ao Jornal do Commercio, jornais de grande tiragem na corte Imperial.

A referência ao fato de José do Patrocínio ocupar o lugar de um "folhetinista brilhante", valia tanto para os libelos contra a escravidão publicados no espaço do rodapé desde a época em que redigia para a Gazeta de Notícias, ${ }^{52}$ como para à produção de romances no espaço do rodapé, entre eles Motta Coqueiro e Os retirantes. Por isso, não é de se estranhar que Pedro Hespanhol divida o espaço do rodapé com um já afamado escritor do gênero, Ponson du Terrail, ao menos nos meses iniciais. Do mesmo modo, nos meses finais - e depois de ocupar sozinho o espaço do rodapé - dividia-o com A Magnetizadora de Jules Mary.

Pedro Hespanhol circulou diariamente entre 6 de abril e 14 de outubro de 1884, na maior parte das vezes, na segunda página do jornal e dividido em duas partes: "A escola do crime" e "Os ladrões de estrada". De acordo com a indicação do jornal, era um "romance original". ${ }^{53}$ Este fato já é bastante esclarecedor de que se tratava de uma história de ficção, traço não tão claro em Pedro Hespanhol de Moreira de Azevedo que, apesar de apresentar elementos que vinculem a história a uma narrativa ficcional, tem a intenção de escrever "episódios históricos".

José do Patrocínio não se preocupa com a referência a fatos reais e, para um leitor desavisado, Pedro Hespanhol era um personagem entre muitos daqueles que circulavam nos rodapés das folhas. Apesar disso, o romance se referia a fatos verídicos - o

52 Ver a tese de SILVA, Ana Carolina Feracin da. Op.cit.

53 Anúncio do folhetim: "Pedro Espanhol. Romance original de José do Patrocínio. Por estes dias." Gazeta da Tarde. 08.01.1884. 
terremoto de Portugal em 1755 - e personagens verídicos - Marquês de Pombal, por exemplo. As ações da primeira parte possuíam esse cenário como pano de fundo.

O enredo apresenta algumas semelhanças com o Pedro Hespanhol de Moreira de Azevedo, mas, de forma geral, as diferenças relacionadas à construção narrativa e aos personagens são significativas. Tais características transformam o romance em uma sequência de sensações, elemento intrínseco aos romances de crime, mostrando que o autor tinha um conhecimento pleno da técnica folhetinesca do corte diário e da construção de efeitos sensacionais.

A primeira parte do romance adia o aparecimento de Pedro Hespanhol. Até o dia 11 de julho, que encerrava metade da narrativa, o personagem principal mal tinha tomado parte em alguns dias de folhetim. Em Moreira de Azevedo a história começava com a indicação do ano de nascimento de Pedro - 1776 - e o relato da intenção do autor:

O herói desta narrativa confessou haver nascido em Portugal, quando interrogado pela polícia na primeira vez que foi preso, mas um comensal asseverou ser ele filho de Cadiz; e como não queremos alterar a verdade histórica, e desejamos proceder como cronista sisudo e grave, não certificamos qual o solo pátrio do nosso famigerado personagem. ${ }^{54}$

Pedro Hespanhol de José do Patrocínio possui delineação distinta ao adiar o aparecimento de Pedro. Apesar disso, o leitor poderia conhecer o personagem. Pode-se concluir isso não apenas pela narrativa anterior de 1872 , como pelas notícias da imprensa que falavam de Pedro desde o ano de 1834. O público sabia da existência do bandido e talvez ansiasse por saber detalhes da história do célebre salteador. 
O último capítulo da primeira parte do romance - "O primeiro crime" - era acerca do assassinato do padrinho por Pedro. A diferença de narrativa entre o Pedro Hespanhol de Moreira de Azevedo e o Pedro Hespanhol de José do Patrocínio é evidente. O momento do crime é adiado e são descritas características relativas ao estado emocional dos personagens. No dia do crime, Pedro acordara feliz: "De manhã a fisionomia de Pedro repassava-lhe de uma alegria estranha. A sua lividez habitual dera lugar a uns tons vermelhos, que chamaram a atenção da própria Catarina" ${ }^{55} \mathrm{O}$ autor criava um estado de suspeição que invoca desconfianças entre os personagens. Ao mesmo tempo, era uma forma de fornecer certo mistério que paira ao longo de toda a narrativa.

Para cada ação, gastavam-se muitas páginas de sensação. Por outro lado, os eventos se desenrolam em uma velocidade frenética. Havia dois tempos narrativos com uma diferença de 30 anos, embora as principais ações se concentrem em poucos dias, assim como havia uma preferência em descrever as ações minuciosamente. Ao contrário de Moreira de Azevedo, que constrói uma narrativa segura, quase automática, próxima do relato, José do Patrocínio consegue produzir um frenesi que torna a leitura mais emocionante. "A escola do crime" era uma verdadeira catástrofe, em que os personagens principais foram levados quase inconscientemente ao caminho do crime. As descrições são chocantes. Mas esta era a intenção do autor: causar sensação a partir de uma determinada forma de narrar.

A segunda parte do romance - "Os ladrões de estrada" incide para as ações de Pedro no Brasil. "Incoerências do amor", título do primeiro capítulo, imprime logo a diferença. Com certa dose de ironia e clara referência aos romances judiciários franceses que tinham como centro da ação um investigador eficiente e excêntrico, ${ }^{56}$ José do Patrocínio descreverá da seguinte maneira o interrogatório de

55 Idem, ibidem, 09.06.1884.

56 Penso nos romances de Émile Gaboriau, escritos entre 1865 e 1873 e que circularam em versões portuguesas e brasileiras no Brasil. Desenvolvo uma pesquisa sobre o escritor em âmbito de pós-doutorado com financiamento da Fapesp. 
Elisa após a súbita intervenção de um "herói" ao violento assalto que sofrera em sua casa: ${ }^{57}$

- Achei-me diante de um grupo de seis homens armados de punhais e que me ordenavam que lhes dissesse onde estava, ou que lhes entregasse tudo que minha mãe possui. Dois desses homens agarraram-me e outros dois apoderaram-se de minha mãe, contra quem levantaram os punhais. Pareceu-me que ia assistir a uma cena fatal; senti no coração uma dor tão aguda, como se já fosse a do cravar dos punhais no peito daquela que me deu o ser. Por um movimento de doida consegui tirar-me das mãos dos miseráveis, fui cair de joelhos ante os dois que ameaçavam minha mãe, e supliquei-lhes que não a maltratassem... Ela não lhe pode fazer mal, não fala, está paralítica... Eu lhes darei tudo, contanto que não torturem esta pobre velha. - Despacha-se, então, disse-me um deles; não temos tempo a perder. Fui rebuscar escaninhos de caixas e gavetas e armários para entregar fielmente tudo. Mas os nossos pequenos teres não contentavam; exigiram que eu dissesse onde estava o dinheiro, que, eles sabiam, nós possuíamos. Ou entrega o dinheiro, ou diz onde ele está ou, então, morrer. Escolha. Não procure mentir porque nem Deus a salva. Calei-me. Vamos: fala ou morre. Neste momento um homem acudiu providencialmente. Trazia duas pistolas engatilhadas, e, com uma coragem, que impunha admiração, ordenou aos bandidos, sob pena de morte, que me deixassem em paz. Os miseráveis, tomados de terror, fugiram. ${ }^{58}$

Ainda no mesmo dia do folhetim, Elisa não consegue descrever o homem que a salvou e afirma que nunca o vira antes. Apresentando o desconhecido como um "ente providencial", o narrador não poupa palavras ao introduzir o salvador de Elisa. O

artigo.

57 Assalto da quadrilha de Pedro. Ver descrição de Moreira de Azevedo, p. 15 deste

58 Idem, ibidem, 14.07.1884. 
intendente sugere, então, que poderia ter sido algum "passeador noturno" ou, como dizia o escrivão, "o chefe da quadrilha":

- Permita que vá em auxílio da memória. É de estatura meiã (sic); reforçado de corpo, olhos grandes, negros, muito vivos e insinuantes, rosto amorenado, barba inteira, muito preta, cabelos também pretos, um tanto compridos, penteados para trás, e caindo um pouco sobre a face, ao menor movimento da cabeça...

- Ele! pensou Elisa, que fingia estar prestando grande atenção aos sinais, quando, em verdade, fazia esforço para não atraiçoar-se.

- Vestia roupa de pano azul e tinha com certeza um rebenquezinho, com corrente de prata na mão.

E sem dar tempo a que Elisa pudesse dominar a sua comoção, continuou:

- Vê o Sr. intendente; fui direto ao ponto. A aparição oportuna, a fuga dos assaltantes, sem altercação, sem luta, tudo isso que pode parecer natural; um transeunte que ouvisse o grito de socorro, e que sendo corajoso entrasse, o terror dos bandidos diante de um homem armado, que eles não sabiam se vinha só ou se era seguido de outros companheiros; tudo isso é o aparato habitual dos assaltos dessa quadrilha infernal, que em vão procuramos capturar, que se esconde não se sabe onde, aparece não se sabe como. Não é verdade que são esses os sinais do homem que a salvou ${ }^{59}$

A moça não responde, mas reconhece no seu íntimo que era essa a exata descrição do seu herói-salvador. O primeiro dia da segunda parte do folhetim apresentava ao leitor as características de Pedro Hespanhol, que aparecia como uma figura quase mitológica. Porém, ainda não se sabia quem era o homem descrito pelo escrivão. O leitor o saberá ao mesmo tempo em que Elisa, no final do número, ainda com o acréscimo de uma característica mais fantasiosa que real:

59 Idem, ibidem. 
- E antes nunca o vira, nem de relance.

- Nunca...

- Talvez não prestasse atenção. Em noite de luar num cavalo ajaezado de prata, sempre a galope..."60

Na última frase, o esclarecimento em relação ao homem que o intendente e o escrivão já sabiam quem era:

\footnotetext{
"Se foi ameaçada, não se arreceie; a sua casa ficará guardada; e apesar da superstição de que não há quem possa prender Pedro, o hespanhol...

- Pedro Hespanhol? exclamou Elisa, que se levantou de um salto e para logo se deixou cair na cadeira. É Pedro Hespanhol...Meu Deus, meu Deus, estou perdida! (continua). ${ }^{61}$
}

A segunda parte de Pedro Hespanhol se refere aos mesmos episódios narrados em Criminosos célebres, porém, apresentados ao leitor em outra ordem e marcando substancialmente a diferença entre essa obra e aquela escrita por Moreira de Azevedo. O gênero romance e a publicação seriada possibilitavam abordagens narrativas que não são tão visíveis em Criminosos célebres. José do Patrocínio escrevia um romance seriado que possuía características bastante claras da irrelevância de comprovação dos fatos narrados, apesar de se referir a personagens verídicos. Ora, para uma obra de rodapé de jornal, não havia a necessidade de provar a verdade dos eventos - o lugar em que fora publicada já dizia, por si só, que se tratava de uma obra ficcional, fato que continua tendo o mesmo efeito com a transformação em volume. Nesse caso, o título já diria o necessário: Pedro Hespanhol. Romance original.

Por outro lado, Criminosos célebres. Episódios históricos, poderia gerar dúvidas em relação ao caráter da obra. Desde o início, o

60 Idem, ibidem.

61 Idem, ibidem. 
autor diz que "deseja proceder como cronista" e que não pretende "alterar a verdade histórica". Porém, como já foi mostrado, era uma biografia ficcional, pois havia um caráter subjetivo que retirava a suposta biografia da condição de um estudo biográfico histórico. ${ }^{62}$ Não ao acaso, o momento de maior sensação era aquele em que havia subjetividade: a morte de Pedro.

A sensação era derivação não apenas das cenas de sangue, mas também da excitação causada por uma narrativa feita aos sobressaltos, com momentos de muita tensão e acontecimentos que se atropelavam uns aos outros e forneciam uma narração dinâmica dos eventos que ocorriam em um período muito curto de tempo. Portanto, ainda seguindo no capítulo 1 da segunda parte, escrivão e intendente acabam o interrogatório e comentam o ocorrido:

- É singular, exclamou o intendente; sabe o que se diz de Pedro Espanhol, e se ele é o terror da própria polícia, o que não será para uma pobre menina que vive num ermo como este.

- Pode bem ser, mas é exagerado o que vemos.

Estas observações foram trocadas à porta da rua. Os dois representantes da autoridade haviam entregado ao cuidado da velha Luíza, Elisa, que conseguira recuperar os sentidos.

- Não lhe parece que devemos fazer vigiar a casa por alguns dias?

- Creio que é um dever, mesmo, para sossegar essa pobre rapariga que é capaz de morrer de medo.

- Bem, oficie neste sentido... Quanto a mim, Sr. escrivão, há um mistério no assalto desta casa. O tal indivíduo que chega a tempo de salvar Elisa das garras de assassinos parece-me personagem de romance.

62 Para esta conclusão sigo a diferenciação feita por COHN, Dorrit. Op.cit., especialmente o capítulo 2 - "Fictional versus Historical Lives: Borderlines and Borderlines Cases". 
- Romance parecerá tudo quanto se contar no futuro, com relação ao famigerado bandido, que nos ilude a todos e zomba desta sociedade inteira. ${ }^{63}$

Com a observação jocosa sobre o caráter lendário de Pedro Hespanhol, José do Patrocínio mostrava que não tinha nenhuma intenção em relacionar a sua narrativa a fatos reais. Ao contrário, enfatizava a característica romanesca criada a partir da memória do famoso bandido até aquele momento, 1884. Assim, brincava com a própria condição de bandido célebre que Pedro Hespanhol havia conquistado, elencando as suas proezas como equivalentes às proezas dos heróis de romance. Fato, aliás, verdadeiro, pois ele era mesmo um "personagem de romance". Por outro lado, isso não impede a existência de um bandido que viveu aquelas aventuras não somente nas páginas de um folhetim, mas durante a sua vida, em um determinado momento histórico - início do século XIX - e nas ruas do Rio de Janeiro.

Com certeza, os leitores da Gazeta da Tarde sabiam da existência de Pedro Hespanhol, o bandido que "zombara de toda a sociedade" (e, acima de tudo, da justiça brasileira). A relação do bandido a um verdadeiro "personagem de romance", feita na narrativa a partir do diálogo entre o intendente e o escrivão, não é irrelevante. Afinal, eles eram os responsáveis pelos interrogatórios, fazendo isso da maneira mais condizente com o fato ocorrido, registrando tudo na minuciosa correção das páginas do processo policial. O desfecho do assalto à casa de Elisa era extraordinário e apenas poderia ser imaginado por essas personagens como uma ação fora da rotina das delegacias.

O romance de José do Patrocínio termina no momento da prisão de Pedro e José com a ajuda dos moradores do local, seguindo a notícia do ano de 1834, assim como havia feito Moreira de Azevedo. A descrição da sua morte na prisão, contudo, não era foco da narrativa. Apesar de diferenças substanciais, os dois Pedros se encontram em algumas passagens comuns aos dois autores. Estas são 
as mesmas que ajudaram a criar uma determinada representação no imaginário da sociedade da época sobre Pedro Hespanhol ou Pedro, o espanhol. Com toda a certeza, Pedro fez parte da história do Império brasileiro.

Agora é possível responder às questões colocadas no início deste artigo. Por que Pedro Hespanhol obteve espaço nos jornais e romances ao longo do século XIX? Respostas definitivas para essas perguntas talvez sejam impossíveis. Contudo, é possível arriscar algumas conclusões. Pedro viveu uma época de intensos debates em torno ao que seria a sociedade brasileira. Ao mesmo tempo em que se tentava criar uma identidade própria e distinta dos portugueses, havia a questão subjacente da escravidão, que permeava todas as relações sociais.

A partir desta perspectiva, um bandido espanhol e branco não era necessariamente um personagem negativo. Assim, criava-se o herói. Notadamente, na mesma década em que a revolta dos Malês assustou a elite brasileira: entre escravos sanguinários e um português-espanhol salteador, o último certamente ocupava o lugar de herói. E, de história em história, construiu-se a lenda.

RECEBIDO EM: 15/05/2016

APROVADO EM: 20/06/2016 